\title{
The Effect of Temperature and Particle Size on the Pyrolysis Products of Waste Tires and the Formation Mechanism of Limonene
}

\author{
LEI GONG ${ }^{1}$, JIN WANG ${ }^{1}$, HONG WEI YU ${ }^{2}$, YING ZHOU ${ }^{1}$, TONG ZOU ${ }^{1}$, HAO NAN ZHANG ${ }^{1}$, \\ JUN ZHOU ${ }^{1 *}$ \\ ${ }^{1}$ College of Environmental and Safety Engineering, Qingdao University of Science and Technology, 53, Zhengzhou Road, \\ Qingdao, 266042, Shandong Province, China \\ ${ }^{2}$ Qingdao Municipal Center for Disease Control \& Prevention, People's Republic of China, Qingdao 266033, Shandong \\ Province, China
}

\begin{abstract}
The rapid development of the automotive industry has led to the accumulation of a large number of waste tires that contain a lot of reusable energy. Macromolecular organics in waste tires can be crack small molecule organics via pyrolysis. In this experiment, thermogravimetry (TG) and pyrolizer-gas chromatography/mass spectrometry (PY-GC/MS) were used to study the pyrolysis behavior of waste tires with different particle sizes, and the effect of temperature and particle size on the pyrolysis products of waste tires under low-temperature pyrolysis conditions, respectively. The volatile substances in waste tires decomposed intensively at $300-500^{\circ} \mathrm{C}$ and were completely pyrolyzed at $500^{\circ} \mathrm{C}$. The content of limonene in the pyrolysis product was significant, and the yield of limonene could reach $27.73 \%$ when the waste tire particles were $0.180-0.250 \mathrm{~mm}$ and the pyrolysis temperature was $380^{\circ} \mathrm{C}$. The mechanism of limonene formation from waste tires was discussed. This study indicated that raw material particle sizes and pyrolysis temperature could change the components and content of pyrolysis products.
\end{abstract}

Keyword: waster tire, pyrolysis, particle size, pyrolysis temperature, limonene

\section{Introduction}

The improvement of life standard among others has promoted automobile production and increased the number of waste tires. In 2019, the number of waste car tires in China were estimated at 330 million, this output rank is the first place in the world. China has promulged a series of policy decrees but has not yet established a complete recycling system for waste tires, which incompletely resolved the accumulation of waste tires. Improper disposal of waste tires is not only wasting rubber resources but also harmful for human health and the environment [1].

The methods of waste tire treatment contain tire retreading, combustion, landfilling and pyrolysis, etc [1]. Only $10 \%$ of waste tires can be used for tire retreading in 2010 [2]. Combustion waste tires may lead to the release of some toxic and harmful substances, e.g., $\mathrm{H}_{2} \mathrm{~S}$, polycyclic aromatic hydrocarbon (PHA) [1, 3]. Waste tires landfill would take up a lot of land resources, adversely affect the long-term settlement and restoration of soil [4-6]. The above methods to treat waste tire is not as an energy resource [7]. In the past decade, pyrolysis could maximize the conversion of waste tires into high-value products is a research subject that researchers focused densely on [8]. Pyrolysis refers to the chemical process of converting rubber into carbon black, high-value fuel oil and fuel gas in the absence of oxygen or the presence of inert gas. This is a high potential, attractively and environmentally friendly method to treat solid waste, which conforms with the principles of reduction, decontamination, treatment and recycling of waste tires [9].

The pyrolysis gas mainly includes ethylene, propylene, butene and isobutylene, the heating value is about 30-40 $\mathrm{MJ} \mathrm{Nm}^{-3}$, and its energy can be used for the pyrolysis process and other applications $[1,10]$. The solid product is mainly carbon black, whose yield decreases with increasing temperature, and is about $32.4 \mathrm{wt} \%$ at $500^{\circ} \mathrm{C}$ [5]. Carbon black can be further processed to be used as activated carbon

*email: zjqkd123456789@163.com 
or reinforcing filler $[11,12]$. Pyrolysis oil is mainly composed of paraffin, olefins and aromatic hydrocarbons. It also has the potential to be a substitute fuel for diesel and gasoline [6, 10]. In addition, pyrolysis products could be reprocessed into light aromatic compounds such as benzene, toluene, xylene and limonene, which have higher market value [13]. The limonene (1-methyl-4-(1-methylethenyl)cyclohexene) in the product is a monoterpene unsaturated hydrocarbon as well as a high-value light hydrocarbon. Limonene can be used as synthetic terpene resin, pressure-sensitive adhesive and hot melt adhesive [14]. Limonene is a kind of widely used green organic solvent, which can be used as a waterinsoluble solvent, insecticide, etc.; because it has antibacterial activity, antioxidant activity, antitumor activity, anti-cough effect and promotes the role of bile secretion in the dissolution of gallstones in the gallbladder, which can be used to treat different types of cancer in the medical field; it acts as an antioxidant, preservative and perfume additive in food additives, and can also be used in the synthesis of phase carvone and menthol. Natural plant oils contain limonene, which can be obtained by pressing, steam distillation, supercritical extraction, etc., and the source of raw materials is relatively single [1416]. The recovery of limonene from the pyrolysis product can make the pyrolysis product more economically valuable.

The pyrolysis product distribution of the waste tire depends on the pyrolysis raw material, particle size, pyrolysis temperature, pyrolysis pressure, catalyst, residence time and carrier gas flow rate [17]. The increase of the pyrolysis temperature has a great influence on the type and content of the pyrolysis product, it also causes the secondary reaction of the pyrolysis product and the decomposition of the inorganic substance [11]. Olefin compounds are further converted into aromatic hydrocarbons through the decomposition of double bonds at a pyrolysis temperature higher than $390^{\circ} \mathrm{C}$ [18]. As temperature rises, the initial pyrolysis products will continue to crack into small molecules, and the pyrolysis gas yield will increase, leading the content of pyrolysis oil to reduce [19]. The increase of particle size affects the temperature distribution inside the particles, the time for complete release of volatiles and the overall pyrolysis rate [20, 21].

At pyrolysis temperature lower than $500^{\circ} \mathrm{C}$, there are few studies on the effect of particle size on pyrolysis products. The target product content is maximized by exploring the proper choice of temperature and particle size. In this investigation, the element content in the waste tire was analyzed by the element analyzer. The effects of temperature and particle size on the pyrolysis behavior of tires and the pyrolysis products were studied. Further, the formation mechanism and process conditions of limonene were explored.

\section{Material and methods}

\subsection{Material preparation}

The used waste tires came from a waste tire recycling station in the city of Qingdao, China. Waste tires were mainly car tires made of natural rubber. First, the waste tires were crushed into small pieces to removed steel wire and other non-rubber materials, then the tire particles were divided into six particles size fractions, i.e.; ( $>0.850 \mathrm{~mm}$ ( $>20 \mathrm{mesh}), 0.425-0.850 \mathrm{~mm}(20-40 \mathrm{mesh}), 0.250-0.425 \mathrm{~mm}$ (40-60 mesh), 0.180-0.250 mm (60-80 mesh), 0.150-0.180 mm (80-100 mesh) and $<0.150 \mathrm{~mm}(<100$ mesh)) through different sizes of meshes (Taylor Standard Sieve). The tire particles were dried in an oven at $40^{\circ} \mathrm{C}$ for $4 \mathrm{~h}[6]$.

\subsection{Element analysis and proximate analysis}

The content of carbon $(\mathrm{C})$, hydrogen $(\mathrm{H})$, nitrogen $(\mathrm{N})$, sulfur $(\mathrm{S})$ in the waste tires was obtained by a CHNS/O analyzer (Vario Micro cube, Elementar) and measured according to JJF 1321-2011. The percentage of oxygen $(\mathrm{O})$ was calculated by the difference in the waste tires. The content of moisture (M), ash (A) and volatile matter (VM) was measured by ASTM D3173-11, ASTM D3174-02 and ASTM D3175-07 standards respectively. The samples were weighed at $1.00 \pm 0.01 \mathrm{mg}$ by using electronic balance and triplicated each time, which was dried in an oven at $500^{\circ} \mathrm{C}$ for $1 \mathrm{~h}$ and cooled to room temperature, the weight loss before and after drying was moisture; which was dried in a muffle furnace 
at $500^{\circ} \mathrm{C}$ for $1 \mathrm{~h}$, heat at $900^{\circ} \mathrm{C}$ for $3 \mathrm{~h}$, and cool to room temperature, the weight of the remaining sample in the crucible was the weight of ash; which was heated in a muffle furnace at $930^{\circ} \mathrm{C}$ for $7 \mathrm{~min}$, and cooled to room temperature in a desiccator, the weight loss before and after heating was the weight of volatiles and moisture. Fixed carbon (FC) was calculated by the formula (1) [7].

$$
F C=100 \%-M-V M-A
$$

\subsection{Thermogravimetric analysis}

The thermogravimetry (TG) method was used to explore the relationship between the weight of matter and temperature to study the thermal stability of investigated materials. The TG was tested via the thermal analyzer (Q500, TA Instruments, USA). The thermal analyzer was increased from room temperature to approximately $700^{\circ} \mathrm{C}$ at a heating rate of $20^{\circ} \mathrm{C} \mathrm{min}{ }^{-1}$. The experiment was run in a nitrogen atmosphere with a flow rate of $100 \mathrm{~mL} \mathrm{~min}{ }^{-1}$. The tire particles were added into the alumina crucible of $6.00 \pm 0.01 \mathrm{mg}$. The real-time changes of the weight were monitored throughout the pyrolysis process [4].

\subsection{Pyrolizer-gas chromatography/mass spectrometer system}

The entire system of pyrolizer-gas chromatography/mass spectrometer (PY-GC/MS) was made of a pyrolizer (EGA/PY3030D, Frontier, Japan) and a gas chromatography/mass spectrometer (GC/MSQP2010, Shimadzu, Japan). The pyrolizer was coupled with the GC/MS to separate the compounds liberated [10,22]. A Rxi-5silMS column (30 m-0.25 mm-0.25 $\mu \mathrm{m})$ was applied in the GC/MS system. The GC/MS program was set as follows: The transfer line (between gas-chromatograph and the mass spectrometer) temperature, ion source temperature and inlet temperature were held at $300^{\circ} \mathrm{C}, 250^{\circ} \mathrm{C}$ and $330^{\circ} \mathrm{C}$, respectively. Under the condition that the heating rate was $5^{\circ} \mathrm{C} \mathrm{min}^{-1}$, the column temperature was kept at $40^{\circ} \mathrm{C}, 130^{\circ} \mathrm{C}$ and $310^{\circ} \mathrm{C}$ for $3 \mathrm{~min}, 1 \mathrm{~min}$ and $10 \mathrm{~min}$ respectively. High-purity helium was used as a carrier gas to pass into the reaction system at a flow rate of $1.75 \mathrm{~mL} \mathrm{~min}^{-1}$.

\subsection{PY-GC/MS experimental procedure}

In the experiments, three different pyrolysis temperatures of $200^{\circ} \mathrm{C}, 380^{\circ} \mathrm{C}$ and $500^{\circ} \mathrm{C}$, i. e. corresponding to the initial pyrolysis temperature, maximum weight loss pyrolysis temperature, and the final pyrolysis temperature, respectively, were taken into account. About $2.00 \pm 0.01 \mathrm{mg}$ of the tire particles were loaded in the crucible each time. The crucible was diverted into the pyrolizer when the pyrolizer reached the desired temperature, and the detected volatiles was identified by comparing the mass spectrum library connected to the PY-GC/MS instrument $[22,23]$. In the experiment, an already mentioned helium was used as the carrier gas, and it was passed into the pyrolizer in advance to create an oxygen-free experimental environment.

\section{Results and discussions}

\subsection{Element analysis and proximate analysis}

The elemental composition of waste tires is very important, as the wt $\%$ or amounts of elements existent in the waste tire can influence pyrolysis rate and the amounts of pyrolysis product $[5,10]$. The wt $\%$ of $\mathrm{C}, \mathrm{H}, \mathrm{N}, \mathrm{S}$ and $\mathrm{O}$ in tires of different particle sizes is listed in Table 1. The proximate analysis of waste tires is tabulated in Table 2. When the particle size was greater than $0.150 \mathrm{~mm}$, the content of $\mathrm{C}, \mathrm{H}, \mathrm{A}, \mathrm{VM}$ and $\mathrm{FC}$ was about $80 \%, 8 \%, 7 \%, 63 \%$ and $25 \%$ respectively. These was very similar to previous research [7]. But when the particle size was less than $0.150 \mathrm{~mm}$, the content of $\mathrm{C}$ and $\mathrm{H}$ was the lowest, $70.85 \%$ and $6.83 \%$, respectively, and the content of A was up to $18.29 \%$. According to Wang et al. [5], the $\mathrm{C}, \mathrm{H}$ and $\mathrm{A}$ content of the tire tread rubber was $56.6 \%, 6.8 \%$, and $18.04 \%$ respectively. Therefore it was speculated that most of the tire particles with a particle size of less than $0.150 \mathrm{~mm}$ belong to the tire tread rubber in the study. It may also be that inorganic components are more likely to be broken into small molecular substances, resulting in a higher A content and lower $\mathrm{C}$ content of the 
particle size $<0.150 \mathrm{~mm}$. The sulfur content found in tire particles was due to the vulcanization process, this was related to the addition of sulfur in the tire manufacturing process [7, 24].

Table 1. Elemental analysis of tire in different particle size ranges

\begin{tabular}{|c|c|c|c|c|c|}
\hline \multirow{2}{*}{$\begin{array}{c}\text { Size } \\
(\mathbf{m m})\end{array}$} & $\mathbf{5}$ & $\mathbf{C}$ & $\mathbf{H}$ & $\mathbf{S}$ & $\mathbf{O}$ \\
\cline { 2 - 6 } & $\mathbf{N}$ & $79.88 \pm 0.46$ & $8.51 \pm 0.26$ & $0.99 \pm 0.05$ & $2.94 \pm 0.96$ \\
\hline $\mathbf{> 0 . 8 5 0}$ & $0.47 \pm 0.23$ & $80.37 \pm 0.85$ & $7.87 \pm 0.19$ & $1.31 \pm 0.02$ & $2.52 \pm 0.81$ \\
\hline $\mathbf{0 . 4 2 5 - 0 . 8 5 0}$ & $0.55 \pm 0.32$ & $80.5 \pm 1.22$ & $7.73 \pm 0.38$ & $1.17 \pm 0.13$ & $2.53 \pm 0.88$ \\
\hline $\mathbf{0 . 2 5 0 - 0 . 4 2 5}$ & $0.55 \pm 0.44$ & $80.71 \pm 0.98$ & $7.61 \pm 0.46$ & $1.16 \pm 0.08$ & $2.44 \pm 0.59$ \\
\hline $\mathbf{0 . 1 8 0 - 0 . 2 5 0}$ & $0.68 \pm 0.23$ & $80.07 \pm 1.02$ & $7.56 \pm 0.28$ & $1.17 \pm 0.14$ & $2.62 \pm 0.82$ \\
\hline $\mathbf{0 . 1 5 0 - 0 . 1 8 0}$ & $0.59 \pm 0.27$ & $70.85 \pm 0.58$ & $6.83 \pm 0.39$ & $1.07 \pm 0.06$ & $3.92 \pm 0.27$ \\
\hline$<\mathbf{0 . 1 5 0}$ & $0.56 \pm 0.35$ & \multicolumn{4}{c}{} \\
\hline
\end{tabular}

Table 2. Proximate analysis of tire in different particle size ranges

\begin{tabular}{|c|c|c|c|c|}
\hline \multirow{2}{*}{ Size(mm) } & \multicolumn{4}{|c|}{ Proximate analysis(wt\%) } \\
\cline { 2 - 5 } & $\mathbf{M}$ & $\mathbf{A}$ & $\mathbf{V M}$ & $\mathbf{F C}$ \\
\hline$>\mathbf{0 . 8 5 0}$ & $4.38 \pm 0.03$ & $7.93 \pm 0.8$ & $62.95 \pm 0.07$ & $24.74 \pm 0.36$ \\
\hline $\mathbf{0 . 4 2 5 - 0 . 8 5 0}$ & $4.23 \pm 0.05$ & $6.67 \pm 0.6$ & $62.63 \pm 0.03$ & $26.47 \pm 0.48$ \\
\hline $\mathbf{0 . 2 5 0 - 0 . 4 2 5}$ & $4.48 \pm 0.02$ & $6.24 \pm 0.5$ & $64.14 \pm 0.04$ & $25.14 \pm 0.52$ \\
\hline $\mathbf{0 . 1 8 0 - 0 . 2 5 0}$ & $3.57 \pm 0.04$ & $7.26 \pm 0.5$ & $63.49 \pm 0.03$ & $25.68 \pm 0.34$ \\
\hline $\mathbf{0 . 1 5 0 - 0 . 1 8 0}$ & $3.50 \pm 0.04$ & $9.16 \pm 1.2$ & $62.51 \pm 0.03$ & $24.83 \pm 0.46$ \\
\hline$<\mathbf{0 . 1 5 0}$ & $4.10 \pm 0.03$ & $18.29 \pm 2.5$ & $50.55 \pm 0.04$ & $27.06 \pm 0.49$ \\
\hline
\end{tabular}

M: Moisture; A: Ash; VM: Volatile matter; FC: Fixed carbon; C: Carbon; H: Hydrogen (includes the hydrogen from water); N: Nitrogen; S: Sulfur.

\subsection{TG and GC/MS analysis}

The curves of TG and derivative thermogravimetry (DTG) for particle size of $>0.850 \mathrm{~mm}, 0.425$ $0.850 \mathrm{~mm}, 0.250-0.425 \mathrm{~mm}, 0.185-0.250 \mathrm{~mm}, 0.150-0.180 \mathrm{~mm}$ and $<0.150 \mathrm{~mm}$ with the increase of temperature is shown in Figure 1(a) and (b), respectively. Using the same particle size, tire pyrolysis could be divided into three stages according to the TG and DTG curves, i.e.; the initial pyrolysis temperature $\left(100-300^{\circ} \mathrm{C}\right)$, maximum weight loss pyrolysis temperature $\left(300-500^{\circ} \mathrm{C}\right)$, and the final pyrolysis temperature $\left(500-680^{\circ} \mathrm{C}\right)$. TG reflected the weight loss rate of the tire was about $6.15 \%$ in the first pyrolysis temperature range. In this stage, the structure of the tire was relatively stable, plasticizers were decomposed, and the tires lose weight slowly [25]. During the maximum weight loss pyrolysis temperature stage, the TG curve drops rapidly (66.71\% and $54.65 \%$, depending on the particle size), and the tire components were rapidly decomposed. This was attributed to the high content of volatiles in the tire and the appearance of concentrated volatilization at $300-500^{\circ} \mathrm{C}$ [11]. In the final pyrolysis temperature range, the synthetic rubber was completely decomposed. When the temperature was higher than $500^{\circ} \mathrm{C}$, the weight was relatively stable, and under this condition, a polycondensation reaction mainly occurred. It was discovered that the thermal decomposition started at $300^{\circ} \mathrm{C}$ and almost was completed at $500^{\circ} \mathrm{C}$, which was consistent with the temperature decomposition range of the tire $[5,8,26]$. DTG represents the connection between the speed of weight loss and temperature. Compared with the TG curve, the DTG curve can observe the degradation rate more clearly [17]. Generally, the higher the DTG value, the faster is the degradation rate. In Figure 1(b), the peak of DTG appeared at $300-500^{\circ} \mathrm{C}$, which is the decomposition behavior of tires because of the rubber in the tires. Simultaneously, this was consistent with the previous study on the decomposition temperature range of natural rubber and synthetic rubber [5, 25]. According to Figure $1(\mathrm{a}, \mathrm{b})$, the three pyrolysis temperatures of initial pyrolysis $\left(200^{\circ} \mathrm{C}\right)$, maximum weight loss rate pyrolysis $\left(380^{\circ} \mathrm{C}\right)$ and final pyrolysis $\left(500^{\circ} \mathrm{C}\right)$ were selected for further study.

When the particle size was less than $0.150 \mathrm{~mm}$, the weight loss was only $54.65 \%$ (Figure 1a), and the DTA peak value was lower than for others particle sizes. It was speculated that this phenomenon was caused by lower rubber content in tire particles. The proximate analysis showing that the VM content of tire particles with particle size less than $0.150 \mathrm{~mm}$ was lower confirms this presumption. 
The GC/MS analysis results of the products of different tire particle sizes at the three pyrolysis temperatures determined by TG analysis are shown in Table 3. The characteristic peaks identification was done by the PBM (Probability Based Matching) algorithm on their spectra [10]. The organic matters that complete the matching were classified according to functional groups and their contents were counted. The type of organic matters in the pyrolysis product increases first and then decreases with the rise of temperature, which is consistent with the analysis results of the TG and DTG curves, shown in Figure 1. The temperature rise was conducive to the progress of the pyrolysis reaction. The higher the temperature, the more secondary reaction can be observed [19].

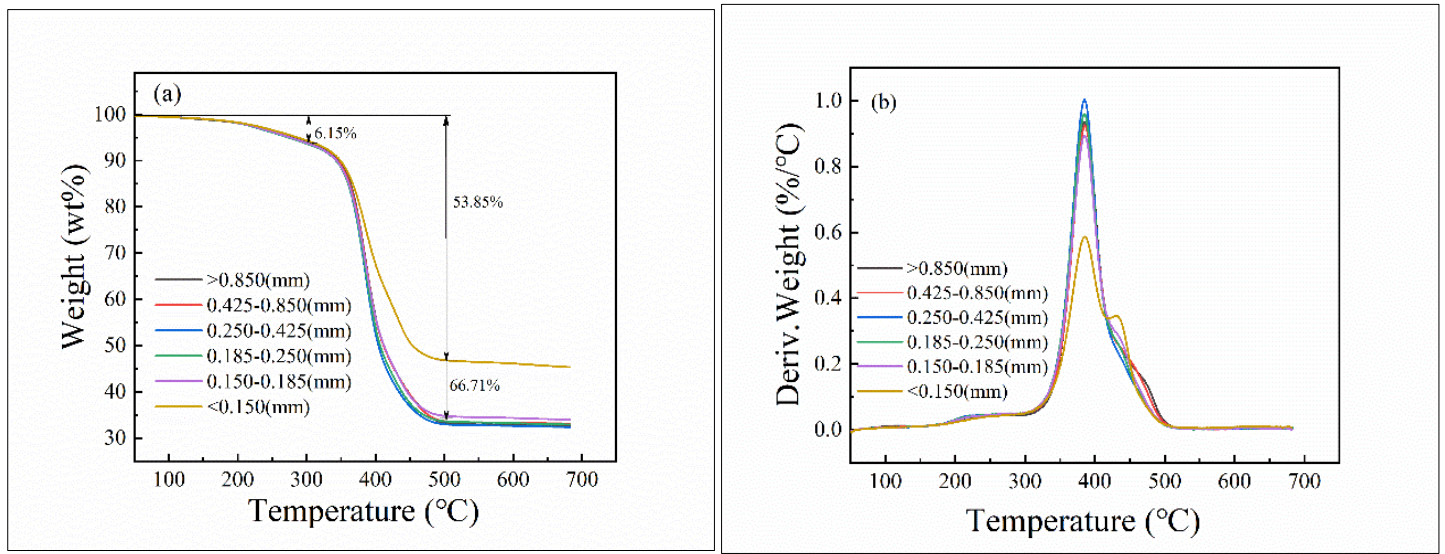

Figure 1. Profile of the a) thermogravimetry (TG) and b) derivative thermogravimetry (DTG) of waste tire particles of different particle sizes, $20^{\circ} \mathrm{C} \mathrm{min}^{-1}$ temperature rate

\subsection{Effect of pyrolysis temperature on pyrolysis products}

Temperature is one of the critical parameters affecting the pyrolysis product yield, as well as heat transfer efficiency, pyrolysis-driven events, and the energy required for pyrolysis [11,27]. In the pyrolysis experiment, the method adopted was to complete the heating process before materials feeding, so that the heating rate would have was no effect. The pyrolysis products at $200^{\circ} \mathrm{C}, 380^{\circ} \mathrm{C}$ and $500^{\circ} \mathrm{C}$ were studied. The types of organic components in the pyrolysis products and the weight loss of tire particles at different pyrolysis temperatures are listed in Table 3. As the pyrolysis temperature was set at $200^{\circ} \mathrm{C}, 380^{\circ} \mathrm{C}$ and $500^{\circ} \mathrm{C}$, the number of organic components included $28 \pm 6,74 \pm 10,33 \pm 5$, respectively. This indicates depending on the particle size that temperature had a significant influence on the types of pyrolysis products. When the temperature was lower than $300^{\circ} \mathrm{C}$, the tire pyrolysis was incomplete, and the rest of the tires was in a state of heterogeneous adhesiveness [7]. According to the thermal analysis, when the pyrolysis temperature was $380^{\circ} \mathrm{C}$, the volatilization rate of volatiles in tire particles was the fastest. The macromolecules in the tire rubber undergo depolymerization and fragmentation and continue to crack into small molecules with the smaller molecular weight with the rise of temperature [28]. In addition, in the pyrolysis product would occur secondary re-polymerization or carbonization reactions under the pyrolysis condition of $500^{\circ} \mathrm{C}$ [7].

The main organic components were determined at the pyrolysis temperature of $200^{\circ} \mathrm{C}$ (Table 4 ), $380^{\circ} \mathrm{C}$ (Table 5) and $500^{\circ} \mathrm{C}$ (Table 6). In the same particle size range, the pyrolysis products mainly included alcohols, nitrogen compounds, acids, esters, and alkanes at the pyrolysis temperature of $200^{\circ} \mathrm{C}$. Pyrolysis products were composed of limonene, olefins, benzenes, alcohols, acids, esters, alkanes, ketones and halogen-containing substances, at $380^{\circ} \mathrm{C}$ pyrolysis temperature. When the tire particles were pyrolyzed at $500^{\circ} \mathrm{C}$, the pyrolysis products could be mainly divided into olefins, benzenes, alcohols, alkanes, halogen-containing substances and sulfur-containing compounds. Maximum nitrogenous substance content (about $50 \%$ ) was obtained at $200^{\circ} \mathrm{C}$. Combined with TG analysis, it is presumed that this result was observed because the additive in the tire was mainly pyrolyzed at this temperature [5]. The content of nitrogenous substances was very closely related to the pyrolysis temperature, but a direct relationship with the content of nitrogen has not been observed. When the pyrolysis temperature was 
$380^{\circ} \mathrm{C}$, the maximum content of aliphatic compounds was $97.62 \%$, of which above $60 \%$ were olefins. This fact can be related to the unsaturated nature of the polymer contained in the tire. The content of benzene species increased from $4.55 \pm 0.50 \%$ at $380^{\circ} \mathrm{C}$ to $15.05 \pm 13.25 \%$ at $500^{\circ} \mathrm{C}$. The increase in the content of benzene species was at the expense of a decrease in aliphatic hydrocarbon content [29]. This was due to the aromatization reaction of pyrolysis products and was a process related to olefin cyclization, dehydrogenation, and Diels-Alder reaction enhancement in the gas phase [7,29,30].

Table 3. Weight loss and compound number for pyrolyzed tires at different temperatures

\begin{tabular}{|c|c|c|c|c|c|c|c|}
\hline $\begin{array}{c}\text { Temperature/ } \\
{ }^{\circ} \mathrm{C}\end{array}$ & $\begin{array}{l}\text { Particle } \\
\text { size/mm }\end{array}$ & $>0.850$ & $0.425-0.850$ & $0.250-0.425$ & $0.180-0.250$ & $0.150-0.180$ & $<0.150$ \\
\hline \multirow{2}{*}{200} & $\begin{array}{c}\text { Types of } \\
\text { pyrolytic } \\
\text { organic matter }\end{array}$ & $23 \pm 2$ & $23 \pm 3$ & $21 \pm 2$ & $22 \pm 1$ & $21 \pm 3$ & $34 \pm 3$ \\
\hline & $\begin{array}{c}\text { Weight loss } \\
\text { percentages/ } \\
\text { wt } \%\end{array}$ & $3.47 \pm 0.43$ & $3.57 \pm 0.18$ & $3.52 \pm 0.27$ & $3.51 \pm 0.41$ & $3.43 \pm 0.37$ & $2.98 \pm 0.27$ \\
\hline \multirow{2}{*}{380} & $\begin{array}{c}\text { Types of } \\
\text { pyrolytic } \\
\text { organic matter }\end{array}$ & $63 \pm 3$ & $70 \pm 4$ & $67 \pm 3$ & $63 \pm 4$ & $80 \pm 5$ & $84 \pm 4$ \\
\hline & $\begin{array}{c}\text { Weight loss } \\
\text { percentages/ } \\
\text { wt } \%\end{array}$ & $54.82 \pm 1.34$ & $55.21 \pm 0.75$ & $57.81 \pm 1.34$ & $56.07 \pm 0.98$ & $54.43 \pm 1.46$ & $39.21 \pm 0.96$ \\
\hline \multirow{2}{*}{500} & $\begin{array}{c}\text { Types of } \\
\text { pyrolytic } \\
\text { organic matter }\end{array}$ & $28 \pm 2$ & $33 \pm 4$ & $34 \pm 2$ & $31 \pm 3$ & $36 \pm 4$ & $37 \pm 2$ \\
\hline & $\begin{array}{l}\text { Weight loss } \\
\text { percentages/ } \\
\text { wt } \%\end{array}$ & $67.33 \pm 0.85$ & $66.86 \pm 1.43$ & $67.62 \pm 1.53$ & $67.06 \pm 1.43$ & $66.01 \pm 1.02$ & $54.6 \pm 1.24$ \\
\hline
\end{tabular}

Table 4. Tentative GC/MS characterization of waste tire pyrolysis products at $200^{\circ} \mathrm{C}$

\begin{tabular}{|c|l|c|c|c|c|c|}
\hline $\begin{array}{c}\text { Particle size/ mm } \\
\text { Compound } \\
\text { species (\% Area) }\end{array}$ & $\mathbf{> 0 . 8 5 0}$ & $\mathbf{0 . 4 2 5 - \mathbf { 0 . 8 5 0 }}$ & $\mathbf{0 . 2 5 0 - 0 . 4 2 5}$ & $\mathbf{0 . 1 8 0 - 0 . 2 5 0}$ & $\mathbf{0 . 1 5 0 - 0 . 1 8 0}$ & $<\mathbf{0 . 1 5 0}$ \\
\hline Alcohols & $2.56 \pm 0.15$ & $2.12 \pm 0.37$ & $2.91 \pm 0.18$ & & $2.66 \pm 0.34$ & $1.15 \pm 0.14$ \\
\hline Nitrogen-containing compound & $54.27 \pm 3.15$ & $34.89 \pm 1.28$ & $53.15 \pm 1.94$ & $47.31 \pm 2.04$ & $46.51 \pm 2.48$ & $50.67 \pm 2.53$ \\
\hline Acids & $18.11 \pm 1.04$ & $37.04 \pm 2.46$ & $18.77 \pm 1.51$ & $30.39 \pm 1.83$ & $28.19 \pm 2.15$ & $4.42 \pm 0.37$ \\
\hline Esters & $3.55 \pm 0.15$ & $5.99 \pm 0.36$ & $3.79 \pm 0.11$ & $1.01 \pm 0.15$ & $3.2 \pm 0.31$ & $29.17 \pm 1.54$ \\
\hline Alkanes & $21.51 \pm 1.34$ & $19.71 \pm 1.62$ & $21.38 \pm 1.57$ & $17.57 \pm 1.42$ & $18.04 \pm 2.05$ & $14.59 \pm 1.61$ \\
\hline
\end{tabular}

Table 5. Tentative gc/ms characterization of waste tire pyrolysis products at $380^{\circ} \mathrm{C}$

\begin{tabular}{|c|c|c|c|c|c|c|}
\hline $\begin{array}{c}\text { Pompound } \\
\text { species (\% Area) }\end{array}$ & $>\mathbf{0 . 8 5 0}$ & $\mathbf{0 . 4 2 5 - 0 . 8 5 0}$ & $\mathbf{0 . 2 5 0 - 0 . 4 2 5}$ & $\mathbf{0 . 1 8 0 - 0 . 2 5 0}$ & $\mathbf{0 . 1 5 0 - 0 . 1 8 0}$ & $<\mathbf{0 . 1 5 0}$ \\
\hline Limonene & $25.33 \pm 1.94$ & $26.14 \pm 1.62$ & $23.58 \pm 1.64$ & $27.73 \pm 0.95$ & $23.2 \pm 1.05$ & $22.5 \pm 0.73$ \\
\hline Olefins & $47.88 \pm 2.04$ & $43.88 \pm 1.27$ & $45.71 \pm 2.37$ & $42.2 \pm 1.24$ & $34.2 \pm 0.67$ & $37.82 \pm 1.27$ \\
\hline Benzene & $3.42 \pm 0.16$ & $4.14 \pm 0.34$ & $4.84 \pm 0.28$ & $4.69 \pm 0.19$ & $5.05 \pm 0.37$ & $5.22 \pm 0.61$ \\
\hline Alcohols & $12.22 \pm 0.84$ & $9.28 \pm 0.61$ & $12.72 \pm 0.42$ & $8.47 \pm 0.37$ & $17.6 \pm 0.66$ & $4.81 \pm 0.27$ \\
\hline Acids & $4.13 \pm 0.24$ & $6.44 \pm 0.38$ & $2.83 \pm 0.13$ & $3.89 \pm 0.25$ & $5.69 \pm 0.73$ & $1.76 \pm 0.61$ \\
\hline Esters & $0.13 \pm 0.06$ & & $1.02 \pm 0.08$ & $1.59 \pm 0.16$ & $0.28 \pm 0.04$ & $1.21 \pm 0.31$ \\
\hline Alkanes & $2.91 \pm 0.42$ & $2.64 \pm 0.16$ & $2.47 \pm 0.15$ & $0.83 \pm 0.36$ & $2.51 \pm 0.41$ & $2.45 \pm 0.17$ \\
\hline Ketones & $0.8 \pm 0.16$ & $1.48 \pm 0.27$ & $1.03 \pm 0.07$ & $0.6 \pm 0.11$ & $3.73 \pm 0.27$ & $2.61 \pm 0.34$ \\
\hline Halogen-containing substance & $3.33 \pm 0.95$ & $3.24 \pm 0.69$ & $4.54 \pm 1.06$ & $3.76 \pm 0.55$ & $3.24 \pm 0.26$ & $1.69 \pm 0.13$ \\
\hline
\end{tabular}


Table 6. Tentative gc/ms characterization of waste tire pyrolysis products at $500^{\circ} \mathrm{C}$

\begin{tabular}{|c|c|c|c|c|c|c|}
\hline $\begin{array}{c}\text { Particle size/ mm } \\
\text { Compound } \\
\text { species (\% Area) }\end{array}$ & $\mathbf{> 0 . 8 5 0}$ & $\mathbf{0 . 4 2 5 - 0 . 8 5 0}$ & $\mathbf{0 . 2 5 0 - 0 . 4 2 5}$ & $\mathbf{0 . 1 8 0 - 0 . 2 5 0}$ & $\mathbf{0 . 1 5 0 - 0 . 1 8 0}$ & $<\mathbf{0 . 1 5 0}$ \\
\hline Olefins & $10.06 \pm 0.55$ & $5.77 \pm 0.48$ & $10.45 \pm 0.39$ & $10.98 \pm 0.64$ & $11.43 \pm 1.06$ & $11.43 \pm 0.64$ \\
\hline Benzene & $22.36 \pm 0.72$ & $28.3 \pm 1.03$ & $19.71 \pm 1.26$ & $9.88 \pm 0.59$ & $5.82 \pm 0.42$ & $0.55 \pm 0.15$ \\
\hline Alcohol & $46.73 \pm 1.35$ & $43.75 \pm 1.27$ & $44.09 \pm 2.15$ & $38.44 \pm 1.33$ & $35.93 \pm 2.13$ & $15.55 \pm 1.85$ \\
\hline Alkane & $19.62 \pm 0.73$ & $20.86 \pm 1.02$ & $16.38 \pm 1.35$ & $28.8 \pm 1.14$ & $9.37 \pm 0.45$ & $7.91 \pm 0.54$ \\
\hline Halogen-containing substance & $1.74 \pm 0.11$ & $1.59 \pm 0.34$ & & $4.1 \pm 0.68$ & $0.81 \pm 0.11$ & $24.48 \pm 2.15$ \\
\hline Sulfur-containing substance & $6.05 \pm 0.53$ & $2.27 \pm 0.26$ & $1.49 \pm 0.18$ & $2.9 \pm 0.26$ & $41.04 \pm 2.58$ \\
\hline
\end{tabular}

\subsection{Effect of tire particle size on pyrolysis products}

It is well known that the particle size of input raw materials has a significant effect on the pyrolysis performance by affecting the internal temperature distribution, heating rate and volatilization residence time [11]. In the experiments, the effect of particle size on the composition of pyrolysis products was studied at the pyrolysis temperatures of $200^{\circ} \mathrm{C}, 380^{\circ} \mathrm{C}$ and $500^{\circ} \mathrm{C}$.

As shown in Table 4, when the particle size was less than $0.150 \mathrm{~mm}$, and the temperature was set to $200^{\circ} \mathrm{C}$, esters obviously increased from $3.20 \%$ to $29.17 \%$. The main ester compounds included bis(2methylpropyl) phthalate, oxalic acid bis(2-ethylhexyl) ester, 2-ethyl octadecyl oxalate, and phthalate-2ethylhexyl-ester (Table 7). Since the small particle size provides a larger specific surface area, the plasticizer involved in the decomposition reaction increased. The most commonly used plasticizer was dibutyl phthalate [17,31]. Approximate analysis shows that tire particles with a particle size of less than $0.150 \mathrm{~mm}$ contain more inorganic components.

As shown in Table 5, when the temperature was $380^{\circ} \mathrm{C}$, with decreases in particle size, the content of benzene derivatives increased slightly, but the content of olefins in contrast. In the thermochemical process, small particles exhibit isothermal behavior and were not limited by internal temperature transfer, which could improve the devolatilization rate of pyrolysis products [15]. The decrease of particle size was conducive to the carbon chain fracture, epoxidation and aromatization of olefins [7]. Primary and secondary reactions can coexist at the same temperature [11]. But in this pyrolysis stage, primary reactions of the tire were dominant, and the aromatization reaction was not violent. When the particle size ranged between $0.180-0.250 \mathrm{~mm}$, more limonene $(27.73 \%$ ) was produced, as can be seen in Table 5. At larger particle sizes, the pyrolysis products cannot be separated from the inside of the particles in time to be further cracked, resulting in a reduction in the content of limonene. It was worth noting that the content of olefins did not show a consistent decrease with the decrease of particle size, and the content of alcohols also shows a fluctuating change. This may be due to the following fact that when the cross-linked structure of the tire was broken under the action of external mechanical force, the structure of the organic matter contained in the tire particles of different particle sizes was different, so the content of the pyrolysis product components presented a fluctuating change.

When the pyrolysis temperature was set to $500^{\circ} \mathrm{C}$, and the particle size was less than $0.180 \mathrm{~mm}$, the sulfide componential content increased significantly to $24.48 \%$ (Table 6). Table 8 displays that the main compound was cyclohexyl methyl pentadecyl sulfite. According to the molecular formula of cyclohexyl methyl pentadecyl sulfite, it is presumed that the increase may be caused by the combination of cyclohexane (monocyclic benzene generated through addition reaction) and sulfur-containing free radicals. When the particle size was less than $0.180 \mathrm{~mm}$, the content of monocyclic benzene species in the pyrolysis product was reduced. Wang et al. [32] found that high pyrolysis temperature would promote the transfer of sulfur to volatile matter. When the particle size was less than $180 \mathrm{~mm}$, it may have a beneficial effect on the transfer of sulfur to volatile matter. 
Table 7. Tentative GC/MS characterization of esters in waste tire pyrolysis products at $200^{\circ} \mathrm{C}$

\begin{tabular}{|c|c|c|c|c|c|c|}
\hline Ester species (\% Area) & $>0.850$ & $0.425-0.850$ & $0.250-0.425$ & $0.180-0.250$ & $0.150-0.180$ & $<0.150$ \\
\hline Methyl hexadecanoate & $0.92 \pm 0.11$ & $0.84 \pm 0.13$ & $1.14 \pm 0.14$ & $1.01 \pm 0.12$ & $1.02 \pm 0.26$ & $1.88 \pm 0.31$ \\
\hline Ethyl hexadecanoate & $0.65 \pm 0.08$ & & $0.79 \pm 0.11$ & & & $0.44 \pm 0.08$ \\
\hline Methyl octadecanoate & $0.56 \pm 0.10$ & & $0.79 \pm 0.15$ & & & \\
\hline Nonyl acetate & $1.04 \pm 0.21$ & $1.06 \pm 0.16$ & $1.07 \pm 0.32$ & & & \\
\hline Oxalic acid, bis(2-ethylhexyl) ester & $0.38 \pm 0.05$ & & & & $1.45 \pm 0.25$ & $6.22 \pm 0.52$ \\
\hline 1,2 phthalic acid, (2, ethylhexyl) ester & $0.38 \pm 0.07$ & $0.3 \pm 0.03$ & & $0.41 \pm 0.08$ & $0.48 \pm 0.13$ & $2.19 \pm 0.26$ \\
\hline Carbonic acid, octadecyl phenyl ester & & $3.79 \pm 0.62$ & & & & \\
\hline $\begin{array}{c}\text { 1,2-phthalic acid, bis(2-methylpropyl) } \\
\text { ester }\end{array}$ & & & & & & $7.77 \pm 0.61$ \\
\hline Dibutyl phthalate & & & & & & $1.13 \pm 0.24$ \\
\hline Isopropyl palmitate & & & & & & $0.44 \pm 0.08$ \\
\hline $\begin{array}{l}\text { 9,12-octadecadienoic acid, methyl } \\
\text { ester }\end{array}$ & & & & & & $0.31 \pm 0.06$ \\
\hline $\begin{array}{l}\text { 2-Acrylic acid, 3-(4-methoxyphenyl)- } \\
\text {,2-ethylhexyl ester }\end{array}$ & & & & & & $1.66 \pm 0.12$ \\
\hline $\begin{array}{l}\text { Caproic acid, 2-ethyl 1,2-oxalyl } \\
\text { bis(oxy-2,1-oxalyl) ester }\end{array}$ & & & & & & $1.26 \pm 0.31$ \\
\hline Oxalic acid, 2-ethyl octadecyl ester & & & & & & $3.7 \pm 0.27$ \\
\hline
\end{tabular}

Table 8. Tentative GC/MS characterization of pyrolysis of benzene series and sulfur-containing substance in waste tire pyrolysis products at $500^{\circ} \mathrm{C}$

\begin{tabular}{|c|c|c|c|c|c|c|}
\hline $\begin{array}{l}\text { Benzene series and } \\
\text { Sulfur-containing substance } \\
\text { (\% Area) }\end{array}$ & $>0.850$ & $\begin{array}{c}0.425- \\
0.850\end{array}$ & $\begin{array}{l}0.250- \\
0.425\end{array}$ & $0.180-0.250$ & $0.150-0.180$ & $<0.150$ \\
\hline P-xylene & $2.62 \pm 0.26$ & $2.31 \pm 0.15$ & & & & \\
\hline 1-ethyl-3-methyl-Benzene & $1.82 \pm 0.19$ & $2.27 \pm 0.22$ & $2.02 \pm 0.43$ & & & \\
\hline 2-ethyl-1,4-dimethyl-Benzene & $0.74 \pm 0.11$ & & & & & \\
\hline (2-methyl-1-propenyl)-Benzene & $0.97 \pm 0.14$ & $2.4 \pm 0.16$ & $2.07 \pm 0.37$ & $1.44 \pm 0.26$ & $0.9 \pm 0.17$ & \\
\hline Benzothiazole & $6.05 \pm 0.62$ & $2.27 \pm 0.14$ & & & & \\
\hline 1,3-dimethyl-1H-Indene & $1.46 \pm 0.35$ & $1.86 \pm 0.21$ & $1.52 \pm 0.33$ & $1.32 \pm 0.22$ & $0.26 \pm 0.08$ & \\
\hline 1,2,3-Trimethylindole & $1.5 \pm 0.08$ & & & & & \\
\hline 2,6-dimethyl-Naphthalene & $0.85 \pm 0.12$ & $1.32 \pm 0.15$ & $0.97 \pm 0.16$ & $1 \pm 0.27$ & $0.55 \pm 0.14$ & \\
\hline 2,4-dimethyl-Quinoline & $0.84 \pm 0.08$ & & & $1.15 \pm 0.28$ & & \\
\hline 2,3,6-trimethyl-Naphthalene & $2.18 \pm 0.26$ & $1.12 \pm 0.17$ & $0.82 \pm 0.24$ & $0.93 \pm 0.14$ & $0.64 \pm 0.16$ & \\
\hline 3-(2-Methyl-propenyl)-1H-indole & $0.44 \pm 0.10$ & & & & & \\
\hline Diphenylamine & $0.69 \pm 0.05$ & $0.81 \pm 0.21$ & $0.85 \pm 0.15$ & $1.76 \pm 0.26$ & $0.37 \pm 0.11$ & $0.14 \pm 0.06$ \\
\hline (4,5,5-trimethyl-1,3-cyclopentadien-1-yl)-Benzene & $0.36 \pm 0.03$ & & & & & \\
\hline 1,2,3,4-tetramethyl-Naphthalene & $1.12 \pm 0.21$ & $1.43 \pm 0.17$ & & & & \\
\hline N-phenyl-1,4-Benzenediamine & $0.72 \pm 0.22$ & $0.89 \pm 0.13$ & $0.73 \pm 0.13$ & $1.21 \pm 0.21$ & & \\
\hline Aniline & & $1.99 \pm 0.25$ & & & & \\
\hline 1,3,5-trimethyl-Benzene & & $4.1 \pm 0.24$ & & & $1.1 \pm 0.13$ & \\
\hline 1-ethyl-2,4-dimethyl-Benzene & & $0.46 \pm 0.15$ & & & $0.23 \pm 0.06$ & \\
\hline 3-ethenyl-1,2-dimethyl-1,4-Cyclohexadiene & & $0.71 \pm 0.22$ & $0.76 \pm 0.22$ & & & \\
\hline 2,3-dihydro-4,7-dimethyl-1H-indole & & $0.93 \pm 0.14$ & & & & \\
\hline 1-methyl-Naphthalene & & $0.81 \pm 0.18$ & $0.66 \pm 0.08$ & $0.65 \pm 0.15$ & & \\
\hline 2,3-dihydro-1,6-dimethyl-1H-indole & & $0.35 \pm 0.08$ & & & & \\
\hline
\end{tabular}




\begin{tabular}{|c|c|c|c|c|c|}
\hline (3-methyl-2-butenyl) Benzene & $\begin{array}{l}1.46 \pm \\
0.22 \\
\end{array}$ & & & & \\
\hline 1,3-dimethyl-1H-indole & $0.81 \pm 0.06$ & & & & \\
\hline (ethoxymethyl)-Benzene & & $3.61 \pm 0.64$ & & & \\
\hline M-xylene & & $1.78 \pm 0.27$ & & & \\
\hline [1-(1,1-dimethylethyl)-3,3-dimethylbutyl]-Benzene & & $0.58 \pm 0.18$ & & & \\
\hline 1-methyl-3-(1-methylethyl)-Benzene & & $0.43 \pm 0.09$ & & & \\
\hline 1-ethyl-2,3-dihydro-1-methyl-1H-Indene & & $1.33 \pm 0.07$ & & & \\
\hline 2,3-dihydro-1,1,5-trimethyl-1H-Indene & & $0.45 \pm 0.11$ & & & \\
\hline 1,1,3-trimethyl-1H-Indene & & $1.13 \pm 0.24$ & & $0.53 \pm 0.14$ & \\
\hline p-tert-butyl-Phenol & & & & & $0.21 \pm 0.03$ \\
\hline 2-(1,1-dimethylethyl)-3-methyl-Phenol & & & & & $0.2 \pm 0.07$ \\
\hline 1-[1-(S)-(dimethylamino)ethyl]-Naphthalene & & & $2.27 \pm 0.26$ & $1.49 \pm 0.24$ & \\
\hline dl-Erythro-1-phenyl-1,2-propanediol & & & $2.27 \pm 0.35$ & $1.49 \pm 0.37$ & \\
\hline 1-Methyl-1,2,3,4-tetrahydronaphthalen-1-ol & & & & $0.56 \pm 0.13$ & \\
\hline 2-(1,1-dimethylethyl)-5-methyl-Phenol & & & & $0.29 \pm 0.08$ & \\
\hline Cyclohexyl methyl pentadecyl sulfite. & & $1.49 \pm 0.26$ & $2.9 \pm 0.61$ & $23.98 \pm 2.31$ & $40.38 \pm 2.58$ \\
\hline bis(1,1,3,3-tetramethylbutyl) Disulfide & & & & $0.5 \pm 0.06$ & $0.15 \pm 0.05$ \\
\hline Sulfurous acid di(cyclohexylmethyl) ester & & & & & $0.51 \pm 0.13$ \\
\hline
\end{tabular}

\subsection{The formation mechanism of limonene}

Limonene was only found in pyrolysis products at the pyrolysis temperature of $380^{\circ} \mathrm{C}$ (Table 4 , Table 5 and Table 6). Chen et al. [16] obtained three exothermic peaks and two endothermic peaks from the DTA thermogram of cis-1,4-polyisoprene at $370^{\circ} \mathrm{C}, 462^{\circ} \mathrm{C}, 544^{\circ} \mathrm{C}$ and $310^{\circ} \mathrm{C}, 408^{\circ} \mathrm{C}$, which explained cis-1,4-polyisoprene basically does not decompose reaction under pyrolysis temperature lower than $310^{\circ} \mathrm{C}$, the pyrolysis product cracking caused the limonene content to decrease at pyrolysis temperature higher than $408^{\circ} \mathrm{C}$. This confirmed that limonene cannot be detected at $200^{\circ} \mathrm{C}$ and $500^{\circ} \mathrm{C}$ pyrolysis products. Pakdel et al. [33] proposed that limonene is the main initial product of rubber pyrolysis. Because the chemical properties of limonene were unstable, decomposition reactions are prone at high temperatures [17]. There are three ways to produce limonene: (1) dimerization of isoprene could generate limonene [34]. Groves et al. [35] assumed that the monomer/dimer ratio increases with increasing temperature and decreases with increasing particle size. Although this path cannot be completely ruled out, the lack of isoprene dimer as a pyrolysis product indicates that this reaction seems impossible to occur in this experiment; (2) The depolymerization of polyisoprene to form a C10 dimer. The activation of this double radical is generated in an oxygen-deficient environment, so it could undergo a cyclization reaction $[36,37]$. This dimer was a short-live radical, which could be driven to limonene by two steps of pyrolysis isomerization. The reaction mechanism is shown in Figure 2. However, this mechanism has not been confirmed by specific experimental data, nor does it specify how polyisoprene forms $\mathrm{C} 10$ dimers. There was no obvious data to prove the existence of $\mathrm{C} 10$ in this reported experiment; (3) The cleavage of the $\beta$-bond between the double bonds in the polydipentadiene chain, and the separated propylene group is internally cyclized to form limonene [30,31]. The bond energy of C-C is lower than $\mathrm{C}=\mathrm{C}\left(347.3 \mathrm{~kJ} / \mathrm{mol}, 611 \mathrm{~kJ} \mathrm{~mol}^{-1}\right.$ respectively) [38], thus in cis-1,4-polyisoprene, the probability of $\mathrm{C}-\mathrm{C}$ bond break is greater than that of $\mathrm{C}=\mathrm{C}$ bond. Due to the difference in bond strength, $\beta$-bond breakage was the most favorable in terms of energy [39]. In the study, the explanation for the formation path of limonene was more inclined to the last one. Figure 3 shows that fracture of the $\beta$ bond in cis-1,4-polyisoprene results in two different allylic radicals, with the radical either two carbons (radical 1) or one carbon (radical 2) separated from the methylated carbon. Under pyrolysis conditions, both of these free radicals could complete the depropagation reaction to obtain the monomer isoprene, 
as shown in Figure 4. Radical 1 would undergo intramolecular cyclization, and then break to generate limonene [40]. The intramolecular cyclization of radical 1 to limonene was presented in Figure 5. The fact was that the cleavage of the $\beta$ bond of the polyisoprene main chain was considered to be more random, radical 1 could continuously reproduce radicals and generate more limonene through the cyclization reaction in Figure 4.

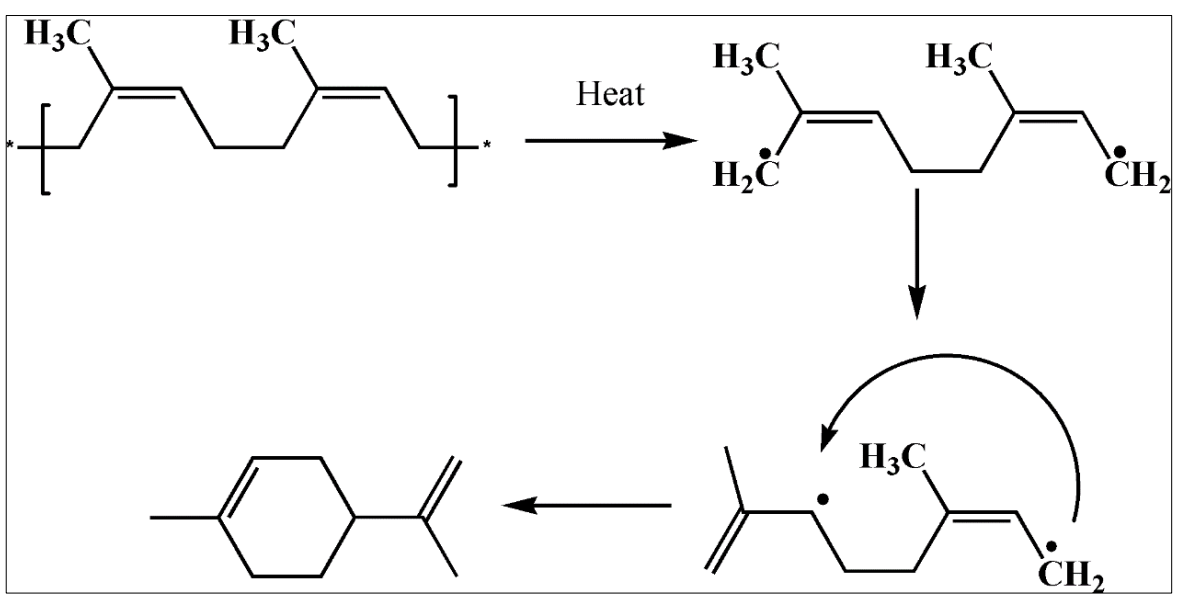

Figure 2. Polyisoprene generates a dimer (C10) free radical, which is then driven to generate limonene by two-step pyrolysis

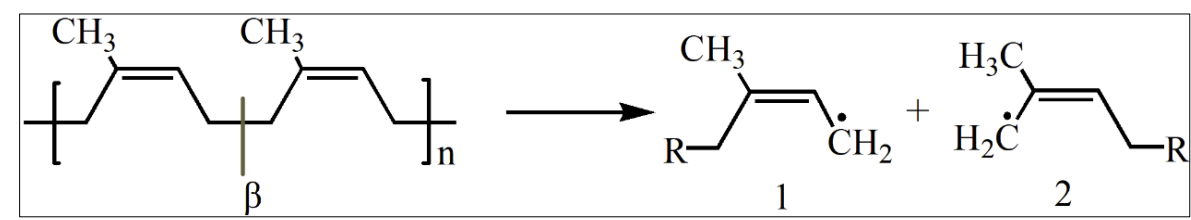

Figure 3. Radical generating depolymerization initiation by scission of the $\beta$ bond with respect to the double bonds in cis-1,4-polyisoprene

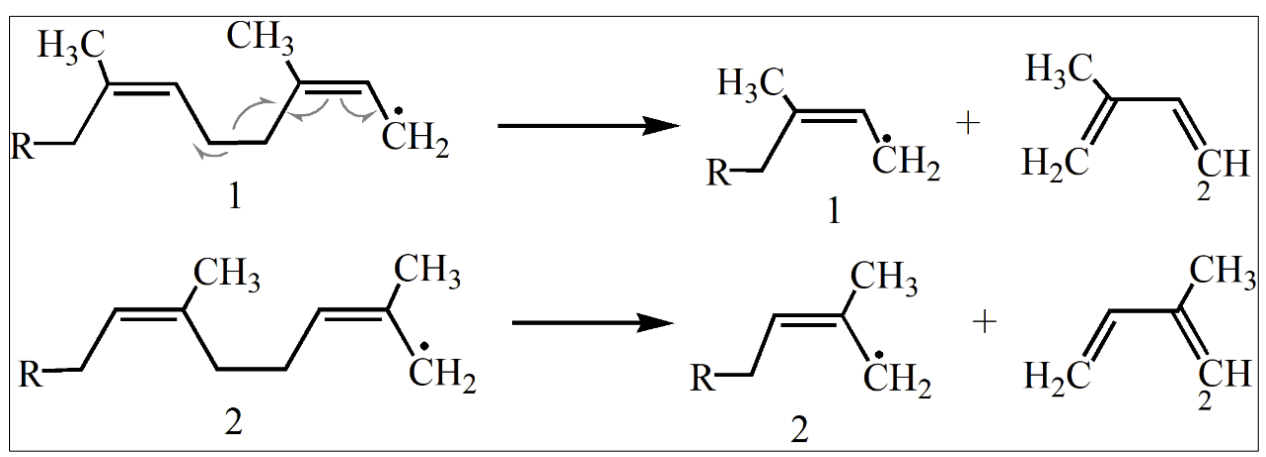

Figure 4. Free radicals 1 and 2 depropagation or decompress to isoprene

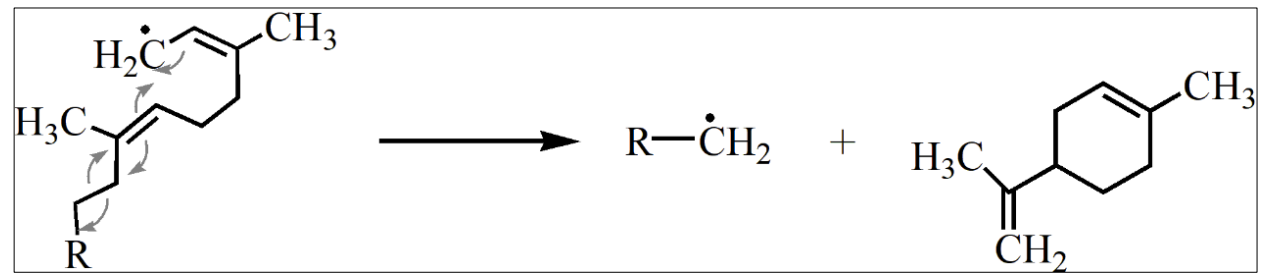

Figure 5. Intramolecular cyclization and scission of allylic radical to form limonene 


\section{Conclusions}

In the experiment reported, the pyrolysis of waste tires was carried out at a pyrolysis temperature of $200^{\circ} \mathrm{C}, 380^{\circ} \mathrm{C}$ and $500^{\circ} \mathrm{C}$. The waste tire particle sizes, which ranged at $>0.850 \mathrm{~mm}, 0.425-0.850 \mathrm{~mm}$, $0.250-0.425 \mathrm{~mm}, 0.180-0.250 \mathrm{~mm}, 0.150-0.180 \mathrm{~mm}$ and $<0.150 \mathrm{~mm}$ was used as the raw material of the pyrolysis process. The results show that the reduction of carbon content will decrease the weight loss rate and the decomposition rate of tires. The pyrolysis behavior of waste tires (all particle sizes) could be divided into three stages: the initial pyrolysis temperature $\left(100-300^{\circ} \mathrm{C}\right)$, maximum weight loss pyrolysis temperature $\left(300-500^{\circ} \mathrm{C}\right)$, and the final pyrolysis temperature $\left(500-680^{\circ} \mathrm{C}\right)$. The aromatization reaction of olefins led to an increase in the content of benzene species with the temperature increased. When the pyrolysis temperature was the same, the fewer the particle sizes, the more product types were formed. At the pyrolysis temperature of $380^{\circ} \mathrm{C}$, as the particle size decreases, the limonene content first increases and then decreases. The content of limonene reached the maximum value of $27.73 \%$ when the particles were $0.180-0.250 \mathrm{~mm}$. The sulfur content increased significantly when the pyrolysis temperature was $500^{\circ} \mathrm{C}$ and the particle sizes were less than $0.180 \mathrm{~mm}$. The irregular change of the composition of pyrolysis products may also be related to the different structures of organic matter in particle size. The formation pathway of limonene may be the cleavage of the $\beta$-bond between the double bonds in cis-1,4polyisoprene to generate free radicals, which undergo intramolecular cyclization. The results of the experiments show that the content of target products such as limonene can be increased by controlling the pyrolysis temperature and the particle size of the raw input materials, while also reducing the content of sulfur-containing substances. The goal of increasing the value of reported tire pyrolysis products has been achieved by the investigation.

\section{References}

1.CZAJCZYŃSKA, D., KRZYŻYŃSKA, R., JOUHARA, H., SPENCER, N. "Use of pyrolytic gas from waste tire as a fuel: A review", Energy, 134, 2017, p. 1121.

https://doi.org/10.1016/j.energy.2017.05.042.

2.TORRETTA, V., RADA, E. C., RAGAZZI, M., TRUlli, E., ISTRATE, I. A., CIOCA, L. I. "Treatment and disposal of tyres: Two EU approaches. A review", Waste Management, 45, 2015, p.152-160. https://doi.org/10.1016/j.wasman.2015.04.018.

3.SU, Y., REN, L., DENG, W. "Experiment Study on NO Reduction by Reburning of Waste Tire", Procedia Environmental Sciences, 18, 2013 p. 359. https://doi.org/10.1016/j.proenv.2013.04.047.

4.CHEN, R., LU, S., ZHANG, Y., \& LO, S. "Pyrolysis study of waste cable hose with thermogravimetry /Fourier transform infrared/mass spectrometry analysis", Energy Conversion and Management, 153, 2017, p. 83-92. https://doi.org/10.1016/j.enconman.2017.09.071.

5.WANG, M., ZHANG, L., LI, A., IRFAN, M., DU, Y., DI, W. "Comparative pyrolysis behaviors of tire tread and side wall from waste tire and characterization of the resulting chars", Journal of Environmental Management, 232, 2019, p. 364-371. https://doi.org/10.1016/j.jenvman.2018.10.091.

6.WANG, W.-C., BAI, C.-J., LIN, C.-T., PRAKASH, S. "Alternative fuel produced from thermal pyrolysis of waste tires and its use in a DI diesel engine", Applied Thermal Engineering, 93, 2016, p. 330. https://doi.org/10.1016/j.applthermaleng.2015.09.056.

7.TALEB, D. A., HAMID, H. A., DERIS, R. R. R., ZULKIFLI, M., KHALIL, N. A., AHMAD YAHAYA, A. N. "Insights into pyrolysis of waste tire in fixed bed reactor: Thermal behavior", Materials Today: Proceedings. 31, no. 1, 2020, p. 178. https://doi.org/10.1016/j.matpr.2020.01.569.

8.KAR, Y. "Catalytic pyrolysis of car tire waste using expanded perlite", Waste Management, 31, no. 8, 2011, p. 1772. https://doi.org/10.1016/j.wasman.2011.04.005.

9.MARTÍNEZ, J. D., MURILLO, R., GARCÍA, T., ARAUZO, I. "Thermodynamic analysis for syngas production from volatiles released in waste tire pyrolysis", Energy Conversion and Management, 81, 2014, p. 338. https://doi.org/10.1016/j.enconman.2014.02.031.

10.AYANOĞLU, A., YUMRUTAŞ, R. "Production of gasoline and diesel like fuels from waste tire oil by using catalytic pyrolysis", Energy, 103, 2016, p. 456. https://doi.org/10.1016/j.energy.2016.02.155. 
11.LUO, S., FENG, Y. "The production of fuel oil and combustible gas by catalytic pyrolysis of waste tire using waste heat of blast-furnace slag", Energy Conversion and Management, 136, 2017, p.27 https://doi.org/10.1016/j.enconman.2016.12.076.

12.YANG, Q., YU, S., ZHONG, H., LIU, T, YAO, E., ZHANG, Y., ZOU, H., DU, W. "Gas products generation mechanism during co-pyrolysis of styrene-butadiene rubber and natural rubber", Waste Management, 118, 2020, p. 9. https://doi.org/10.1016/j.jhazmat.2020.123302.

13.ROFIQULISLAM, M., HANIU, H., RAFIQULALAMBEG, M. "Liquid fuels and chemicals from pyrolysis of motorcycle tire waste: Product yields, compositions and related properties", Fuel, 87, no. 13-14, 2008, p. 3112. https://doi.org/10.1016/j.matpr.2020.04.797.

14.DANON, B., GRYP P. V. D., SCHWARZ, C. E., GÖRGENS, J.F. "A review of dipentence (DL limonene) production from waster tire pyrolysis", Journal of Analytical and Applied pyrolysis, 112, 2015, p. 1. https://doi.org/10.1016/j.jaap.2014.12.025.

15.LARSEN, M., SCHULTZ, L., GLARBORG, P., SKAARUPJENSEN, L., DAMJOHANSEN, K., FRANDSEN, F., HENRIKSEN, U. "Devolatilization characteristics of large particles of tyre rubber under combustion conditions", Fuel, 85, no. 10-112006, p. 1335.

https://doi.org/10.1016/j.fuel.2005.12.014.

16.CHEN, F. "Studies on the thermal degradation of cis-1,4-polyisoprene", Fuel, 81, no. 16, 2002, p. 2071.https://doi.org/10.1016/S0016-2361(02)00147-3

17.MARTINEZ, J-D., PUY, N., MURILLO, R., GARCÍA, T., NAVARRO, M-V., "Waste tyre pyrolysis - A review", Renewable and Sustainable Energy Reviews, 23, 2013, p. 179.

https://doi.org/10.1016/j.rser.2013.02.038

18.MIRANDA, M., PINTO, F., GULYURTLU, I., CABRITA, I. "Pyrolysis of rubber tyre wastes: A kinetic study", Fuel, 103, 2013, p. 542. https://doi.org/10.1016/j.fuel.2012.06.114.

19.DONG, R., ZHAO, M., XIA, W., YI, X., DAI, P., TANG, N. "Chemical and microscopic investigation of co-pyrolysis of crumb tire rubber with waste cooking oil at mild temperature" Waste Management, 79, 2018, p. 516. https://doi.org/10.1016/j.wasman.2018.08.024.

20.MARKOŠ, J. HAYDARY, J., JELEMENSKÝ, L', GAŠPAROVIČ, L., MARKOŠ, J. "Influence of particle size and kinetic parameters on tire pyrolysis", Journal of Analytical and Applied Pyrolysis, 97, 2012, p. 73. https://doi.org/10.1016/j.jaap.2012.07.003.

21.OYEDUN, A., LAM, K.-L., FITTKAU, M., HUI, C.-W. "Optimisation of particle size in waste tyre pyrolysis", Fuel, 95, 2012, p. 417. https://doi.org/10.1016/j.fuel.2011.09.046.

22.WANG, Z., MA, R., SONG, W. "Influence of HSAPO-34, HZSM-5, and NaY on pyrolysis of corn straw fermentation residue via Py-GC/MS", Journal of Analytical and Applied Pyrolysis, 122, 2016, p. 183. https://doi.org/10.1016/j.jaap.2016.09.025.

23.CHEN, W.-H., WANG, C.-W., KUMAR, G., ROUSSET, P., HSIEH, T.-H. "Effect of torrefaction pretreatment on the pyrolysis of rubber wood sawdust analyzed by Py-GC/MS", Bioresource Technology, 259, 2018, p. 469. https://doi.org/10.1016/j.biortech.2018.03.033.

24.CORAN, A.Y. 7-Vulcanization. "Science and Technology of Rubber (Second Edition) ", 1994, p. 339. https://doi.org/10.1016/B978-0-08-051667-7.50012-3.

25.HAN, J., LI, W., LIU, D., QIN, L., CHEN, W., XING, F. "Pyrolysis characteristic and mechanism of waste tyre: A thermogravimetry-mass spectrometry analysis", Journal of Analytical and Applied Pyrolysis, 129, 2018, p. 1. https://doi.org/10.1016/j.jaap.2017.12.016.

26.MARTÍNEZ, J.D, MURILLO, R, GARCÍA, T. "Production of carbon black from the waste tires pyrolysis", 2013, p. 10. http://hdl.handle.net/10261/102706.

27.EDWIN RAJ, R., ROBERT KENNEDY, Z., PILLAI, B. C. "Optimization of process parameters in flash pyrolysis of waste tyres to liquid and gaseous fuel in a fluidized bed reactor", Energy Conversion and Management, 67, 203, p. 145. https://doi.org/10.1016/j.enconman.2012.11.012.

28.DONG, R., ZHAO, M. "Research on the pyrolysis process of crumb tire rubber in waste cooking oil", Renewable Energy, 125, 2018, p. 557. https://doi.org/10.1016/j.renene.2018.02.133. 
29.AHMAD, N., ABNISA, F., WAN DAUD, W. M. A. "Liquefaction of natural rubber to liquid fuels via hydrous pyrolysis", Fuel, 218, 2018, p. 227. https://doi.org/10.1016/j.fuel.2017.12.117.

30.ZHANG, X., WANG, T., MA, L., CHANG, J. "Vacuum pyrolysis of waste tires with basic additives", Waste Management, 28, 2008, p. 2301. https://doi.org/10.1016/j.wasman.2007.10.009.

31.IDRIS, R., CHONG, C. T., ASIK, J. A., ANI, F. N. "Optimization studies of microwave-induced copyrolysis of empty fruit bunches/waste truck tire using response surface methodology", Journal of Cleaner Production, 244, 2020, p. 118649. https://doi.org/10.1016/j.jclepro.2019.118649.

32.WANG, H., HU, H., YANG, Y., LIU, H., TANG, H., XU, S., LI, A., YAO, H. "Effect of high heating rates on products distribution and sulfur transformation during the pyrolysis of waste tires", Waste Management, 118, 2020, p. 9. doi:10.1016/j.wasman.2020.08.015

33.PAKDEL, H., PANTEA, D. M., ROY, C. "Production of dl-limonene by vacuum pyrolysis of used tires", Journal of Analytical and Applied Pyrolysis, 57, no. 1, 2011, p. 91.

https://doi.org/10.1016/S0165-2370(00)00136-4.

34.PAKDEL, H., ROY, C., AUBIN, H., JEAN, G., COULOMBE, S. "Formation of dl-limonene in used tire vacuum pyrolysis oils", Environmental Science \& Technology, 25, no. 9, 1991, p.1646

https://doi.org/10.1021/es00021a018.

35.GROVES, S. A., LEHRLE, R. S., BLAZSÓ, M., SZÉKELY, T. "Natural rubber pyrolysis: Study of temperature-and thickness-dependence indicates dimer formation mechanism", Journal of Analytical and Applied Pyrolysis, 19, 1991, p. 301. https://doi.org/10.1016/0165-2370(91)80051-9.

36.SAUER, J. "Diels-Alder reactions II: The Reaction Mechanism", Angewandte Chemie International Edition in English, 6, no.1, 1967, p. 16. https://doi.org/10.1002/anie.196700161.

37.HENNIS, H.E. "Diels-Alder reactions. II. The independence of reaction tempera-ture and mode of addition in isoprene-methyl acrylate Diels-Alder reaction", The Journal of Organic Chemistry, 28, 1963, p. 2570. http://dx.doi.org/10.1021/jo01045a020.

38.MANGESH, V.L., PADMANABHAN, S., TAMIZHDURAI, P., RAMESH, A. "Experimental investigation to identify the type of waste plastic pyrolysis oil suitable for conversion to diesel engine fuel", Journal of Cleaner Production, S0959-6526, no. 19, p. 33936.

https://doi.org/10.1016/j.jclepro.2019.119066.

39.BHOWMICK, A. K., RAMPALLI, S., GALlAGHER, K., SEEGER, R., MCINTYRE, D. "The degradation of guayule rubber and the effect of resin components on degradation at high temperature", Journal of Applied Polymer Science, 33, no. 4, 1987, p. 1125

https://doi.org/10.1002/app.1987.070330407.

40.CHIEN, J. C. W., KIANG, J. K. Y. "Polymer reactions -X thermal pyrolysis of poly(isoprene) ", European Polymer Journal, 15, no. 1, 1979, p. 1059. https://doi.org/10.1016/0014-3057(79)90146-0.

$\overline{\text { Manuscript received: } 7.03 .2021}$ 